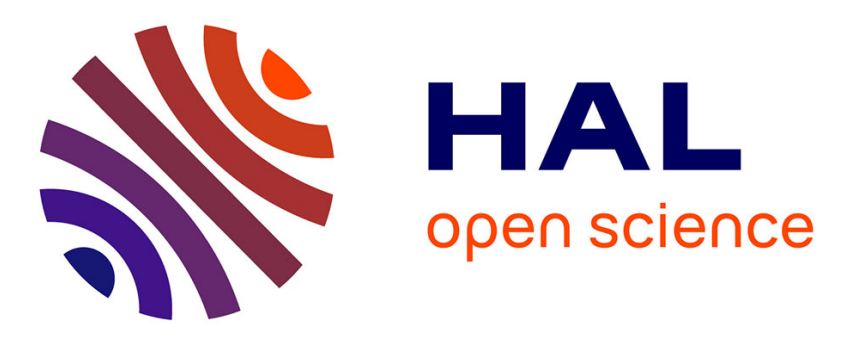

\title{
Triterpenoid profiles of the leaves of wild and domesticated grapevines
}

Aleksandra Burdziej, Cezary Pączkowski, Agnes Destrac-Irvine, Tristan Richard, Stéphanie Cluzet, Anna Szakiel

\section{To cite this version:}

Aleksandra Burdziej, Cezary Pączkowski, Agnes Destrac-Irvine, Tristan Richard, Stéphanie Cluzet, et al. Triterpenoid profiles of the leaves of wild and domesticated grapevines. Phytochemistry Letters, 2019, 30, pp.302-308. 10.1016/j.phytol.2019.02.009 . hal-02626916

\section{HAL Id: hal-02626916 https://hal.inrae.fr/hal-02626916}

Submitted on 22 Oct 2021

HAL is a multi-disciplinary open access archive for the deposit and dissemination of scientific research documents, whether they are published or not. The documents may come from teaching and research institutions in France or abroad, or from public or private research centers.
L'archive ouverte pluridisciplinaire HAL, est destinée au dépôt et à la diffusion de documents scientifiques de niveau recherche, publiés ou non, émanant des établissements d'enseignement et de recherche français ou étrangers, des laboratoires publics ou privés.

\section{다)(1) $(5$}

Distributed under a Creative Commons Attribution - NonCommerciall 4.0 International 


\section{Triterpenoid profiles of the leaves of wild and domesticated}

\section{grapevines}

Aleksandra Burdziej a,b*, Cezary Pączkowski a , Agnès Destrac-Irvine ${ }^{\mathrm{c}}$, Tristan Richard ${ }^{\mathrm{b}}$, Stéphanie Cluzet ${ }^{\mathrm{b}}$, Anna Szakiel ${ }^{\mathrm{a}}$

a Department of Plant Biochemistry, Faculty of Biology, University of Warsaw, Ilji Miecznikowa 1, 02-096 Warszawa, Poland

${ }^{\mathrm{b}}$ Univ. Bordeaux, Faculté des Sciences Pharmaceutiques, Unité de recherche Enologie, EA 4577, USC 1366 INRA, Equipe Molécules d'Intérêt Biologique (GESVAB), ISVV, 33882 Villenave d'Ornon cedex, France

${ }^{\mathrm{c}}$ UMR EGFV, Bordeaux Sciences Agro, INRA, Univ. Bordeaux, Villenave d'Ornon, 33882, France

*Corresponding author:

aleksandra.burdziej@ biol.uw.edu.pl, tel. +48225543321, fax +48225543221

e-mail addresses of other authors:

C. Pączkowski myhacp@biol.uw.edu.pl, A. Destrac-Irvine agnes.destrac-irvine@inra.fr, T. Richard tristan.richard@u-bordeaux.fr, S. Cluzet stephanie.cluzet@u-bordeaux.fr, A. Szakiel szakal@biol.uw.edu.pl

\section{Abstract}

The composition of steroids and triterpenoids in the leaves of eight grapevine species was analyzed in order to assess phenotypic differences. Four wild species (Vitis aestivalis Michx., 
Vitis labrusca L., Vitis riparia Michx., and Vitis vinifera subsp. sylvestris (Gmelin) Hegi) and four domesticated (Vitis vinifera cultivars: Cabernet Sauvignon, Gamay, Marselan, and Merlot) were studied. Although the main profiles of steroids and triterpenoids were similar in all analyzed extracts, remarkable quantitative differences in the content of these compounds in Vitis spp. leaves were demonstrated by GC-MS/FID analysis. The analyzed Vitis plants differed in the level of phytosterols, i.e. cholesterol (1), campesterol (2), stigmasterol (3), clionasterol (4) (exclusively in V. vinifera subsp. sylvestris (Gmelin) Hegi), sitosterol (5), and their amount was generally higher in wild grapevines. The predominance of pentacyclic triterpenoids of ursane-, oleanane-, lupane- and friedooleanane (taraxerane)-type skeletons depended on the studied cultivar/variety. Taraxerol (7) may be considered as a biomarker compound of $V$. vinifera leaves. The obtained data supplement information about biochemical diversity of Vitis genus and despite small qualitative differences allow species discrimination considering phylogenetic relationships confirmed by HCPC analysis. Differences between wild and cultivated grapevines in steroid and triterpenoid profiles may be connected to the domestication process.

\section{Keywords:}

Vitis spp.; Grapevine; Triterpenoids; Steroids; GC-MS/FID

\section{Introduction}

Grapevine (Vitis spp.) is one of the most ancient cultivated plants playing a primary role in culture and economics of many countries. Several crucial incidences in the history of its 
cultivation, such as 'phylloxera crisis' of the second half of the $19^{\text {th }}$ century, the great frost of 1956 and the development of multiplication techniques like grafting or clonal selection, have significantly contributed to the polymorphism of the present-day grapevines. A considerable diversity in the biosynthetic abilities of its varieties is linked to this heterogeneity. A majority of the studies on Vitis plants have focused on polyphenolic compounds, particularly the stilbenes which are considered as the key defensive secondary compounds (phytoalexins) produced by grapevine in response to microbial infections. In contrast, information on triterpenoids in grapevine is rather scarce. Nevertheless, several authors have reported the presence of triterpenoid compounds as constituents of cuticular waxes in different varieties of Vitis spp. leaves (Batovska et al., 2008, 2009, 2010; Berli et al., 2010; Özer et al., 2017; Pensec et al., 2016). A role of triterpenoids in plant defense responses to biotic and abiotic factors is suggested as the cuticular waxes are considered to be the first line of protection towards different stresses. The modifications in the content of the membrane-related triterpenoids, i.e. sterols, and some pentacyclic triterpenes like lupeol, $\alpha$ - and $\beta$-amyrins, were shown to be associated with environmental adaptation of grapevine during seasonal variations and to UV radiations as an indirect consequence of abscisic acid (ABA) signalling (Berli et al., 2010; Batovska et al., 2008, 2009; Gil et al., 2012). The seasonal accumulation of triterpene monohydroxy alcohols is suggested to be associated with the repulsion of microorganisms attacking in the autumn (Batovska et al., 2009). Indeed, the toxicity of $\alpha$ amyrin, lupeol, and taraxerol towards insects was reported and it may result from the ability of these molecules to inhibit acyl chain packing in lipid bilayers (Rodríguez et al., 1997). Some triterpenoids, as $\alpha$-amyrin, lupeol, stigmasta-3,5-diene-7-one, are proposed as biomarkers for the prediction of resistance to grapevine pathogens, such as Plasmopara viticola or Erysiphe necator, responsible of downy and powdery mildews, respectively 
(Batovska et al., 2008, 2009). However, triterpenoids are generally regarded as constitutive plant defense molecules (i.e. phytoanticipins) rather than phytoalexins (Pensec et al., 2016). The aim of the present study was a comparison of triterpenoid content in the whole leaf tissue of wild grapevine crops used as progenitors or rootstocks of domesticated vines (Vitis aestivalis Michx., Vitis labrusca L., Vitis riparia Michx., and Vitis vinifera subsp. sylvestris (Gmelin) Hegi), and of typical cultivated Vitis vinifera varieties from different French vineyards (Cabernet Sauvignon, Gamay, Marselan, and Merlot). Crop wild relatives (CWRs) constitute a unique genetic resource, essential for the improvement and creation of the "new" grapevine thanks to their potential in production diversity. This material is also often at the origin of the rootstock varietal creations, as wild Vitis from North America for their ability to provide pathogen or pests resistance. The domesticated $V$. vinifera plants used in this study are cultivated in the frame of the "Vitadapt" project designed to an extensive phenotyping of a wide range of varieties in order to optimize the use of genetic diversity within the Vitis species as a tool for adaptation to a changing environment (Van Leeuwen and Destrac-Irvine, 2017; De Cortázar-Atauri et al., 2017). The wild grapevines belong to a collection of INRA (Villenave d'Ornon) in order to preserve these species. The obtained results supplement existing data about steroid and triterpenoid profile of different Vitis spp., particularly in the whole leaf tissue, and can contribute to the explanation of variability among grapevine species in the context of their chemical characterization. The information about the steroid and triterpenoid content in grapevine leaves might help to better understand their role in plant defense and could support their application in traditional food and in folk medicine as a remedy for the treatment of diarrhea, vomiting, and some circulatory system diseases (Orhan et al., 2009; Pacifico et al., 2013). The numerous biological activities of this nutritial matrix are mainly attributed to phenolic compounds, and the investigation of potential 
pharmacological effect of triterpenoids is neglected, although some of these molecules possess diverse antimicrobial and cytotoxic properties (Shai et al., 2008).

\section{Results and discussion}

\subsection{Identification of steroids and triterpenoids occurring in leaves of Vitis spp.}

A GC-MS analysis of the fractions containing steroids and neutral pentacyclic triterpenoids obtained from diethyl ether extracts of leaves of different Vitis plants was performed. Representative chromatograms are shown in Figure 1. They revealed rather similar general profile in "steroid and triterpenoid range" (retention time higher than 32 min in the applied program). The identification of the compounds associated with individual peaks revealed the occurrence of several steroids: cholesterol (1) ( $\mathrm{t}_{R}$ of $\left.31.41 \mathrm{~min}\right)$, campesterol (2) $\left(\mathrm{t}_{R}\right.$ of $\left.34.26 \mathrm{~min}\right)$, stigmasterol (3) ( $\mathrm{t}_{R}$ of $\left.35.19 \mathrm{~min}\right)$, sitosterol $(\mathbf{5})\left(\mathrm{t}_{R}\right.$ of $\left.37.28 \mathrm{~min}\right)$ as well as pentacyclic compounds of ursane-, oleanane-, lupane- and friedooleanane (taraxerane)-type skeletons, i.e. $\alpha$-amyrin (11) ( $\mathrm{t}_{R}$ of $\left.40.05 \mathrm{~min}\right), \beta$-amyrin $(\mathbf{8})\left(\mathrm{t}_{R}\right.$ of $\left.38.29 \mathrm{~min}\right)$, lupeol (10) $\left(\mathrm{t}_{R}\right.$ of $40.05 \mathrm{~min})$ and taraxerol (7) ( $\mathrm{t}_{R}$ of $\left.37.62 \mathrm{~min}\right)$, respectively. Lupeol (10) and $\alpha$-amyrin (11) were identified as a mixture associated with one common peak, since they are not well separated on the applied GC-MS column, as described earlier (Pensec et al., 2016). According to the observed MS distribution, lupeol several times prevailed $\alpha$-amyrin. One of the intermediates of sterol biosynthetic pathway, 24-methylenecycloartanol (12) ( $\mathrm{t}_{R}$ of $\left.41.87 \mathrm{~min}\right)$, is also found in detectable amounts in all analyzed extracts. In two extracts obtained from wild grapevine species: $V$. labrusca L. and $V$. riparia Michx sitosterol was accompanied by its saturated form, sitostanol $(6)\left(t_{R}\right.$ of $\left.37.41 \mathrm{~min}\right)$. Two esters, which cofractionated with free triterpenoids, i.e. sitosterol and lupeol acetates $\left(\mathbf{9}\right.$ and $\mathbf{1 3}, \mathrm{t}_{R}$ of $39.11 \mathrm{~min}$ and $\mathrm{t}_{R}$ of $42.93 \mathrm{~min}$, respectively), were identified in the majority of analyzed extracts. In turn, the sitosterol $\gamma$ isomer, clionasterol (4) ( $\mathrm{t}_{R}$ of $36.92 \mathrm{~min}$ ), was found exclusively in $V$. vinifera subsp. 
sylvestris (Gmelin) Hegi. In some extracts, traces of ursane-type ketone, $\alpha$-amyrenone, were detected, however, in amounts too low for FID quantitation. The chemical structures of the major identified compounds are shown in Figure 2. Other numerous peaks, with retention times up to $30 \mathrm{~min}$ and displaying various intensities, were associated with aliphatic or phenolic compounds. Two peaks of $\mathrm{t}_{R} 30.03$ and 32.05 min were identified as typical phenol/diterpenoid antioxidants: $\gamma$ - and $\alpha$-tocopherol, respectively.

The obtained results generally confirm the reported findings of several previous studies on triterpenoids occurring in grapevine leaves (Batovska et al., 2008, 2009, 2010; Berli et al., 2010, Pensec et al., 2016). In the study performed on profiling of grapevine leaf cuticular waxes of eight V. vinifera cultivars from the Upper Rhine Valley (Pensec et al., 2016), additionally cycloartanol, oleanolic aldehyde as well as stigmasta-3,5-dien-7-one were found. However, the cited work had been done on cuticular waxes, which facilitated chromatographic fractionation and permitted easier and more precise identification of compounds due to lower levels of contaminants - by contrast to the present study made on extracts obtained from entire leaves. It was previously demonstrated that the compounds present in very low amounts, which could be found in cuticular wax extracts, were not detectable in extracts obtained from entire plant organs (Szakiel et al., 2012b).

Although the composition of steroids and triterpenoids was similar in all wild and domesticated grapevines studied, the various intensity of individual peaks associated with identified compounds suggested the significant differences in their content among the analyzed species and cultivars.

\subsection{Quantitative analysis of triterpenoids occurring in leaves of Vitis spp.}

The results of quantitative determination of steroids and triterpenoids in extracts of studied wild and domesticated grapevine leaves are presented in Tables 1 and 2, respectively. 
In addition, Figure 3 shows quantitative profiles of pentacyclic triterpenoids occurring in grapevine leaves.

Generally, the total content of analyzed compounds ranged from $1.0 \mathrm{mg} / \mathrm{g}$ of dry leaf weight in domesticated Merlot cultivar to $2.7 \mathrm{mg} / \mathrm{g}$ in wild $V$. labrusca $\mathrm{L}$. The average total content was lower in leaves of domesticated cultivars (approx. $1.7 \mathrm{mg} / \mathrm{g}$, ranging from 1.0 to $2.4 \mathrm{mg} / \mathrm{g}$ ) than in wild grapevines (approx. $2.0 \mathrm{mg} / \mathrm{g}$, ranging from 1.6 to $2.7 \mathrm{mg} / \mathrm{g}$ ).

The total content of sterols ranged from $0.6 \mathrm{mg} / \mathrm{g}$ of dry leaf weight in extract from Merlot to $1.7 \mathrm{mg} / \mathrm{g}$ in Marselan. The average sterol content was similar in leaves of wild and domesticated grapevines and equalled approx. $1 \mathrm{mg} / \mathrm{g}$. However, the content of sterols in wild grapevines seems to be more stable and uniform among species, since the fluctuation between the lowest and the highest content did not exceed $0.2 \mathrm{mg}$, that is, $16 \%$ of the highest amount. On the contrary, the difference between the lowest and the highest content of sterols in domesticated grapevines exceeded $1 \mathrm{mg}$, that is, $63 \%$ of the highest amount. Sitosterol was the most abundant compound in the sterol profile of all analyzed grapevines, constituting from $63 \%$ of the total sterol content in V. labrusca L. to $80 \%$ in Gamay cultivar. The smallest amount of sitosterol was detected in V. vinifera subsp. sylvestris (Gmelin) Hegi (only $41 \%$ of the total sterol content), however, as it was described above, in this species also the sitosterol $\gamma$-isomer, clionasterol, was found in remarkable amount, and together these two isomers constituted $72 \%$ of the total sterol content. The second abundant sterol in the wild species was stigmasterol, with the exception of $V$. labrusca L., in which 24-methylenecycloartanol was prevailing. In the domesticated species, the second abundant compound among steroids was 24-methylenecycloartanol, whereas stigmasterol was prevailing only in Cabernet Sauvignon cultivar. The content of the third phytosterol, campesterol, was in average more than twice higher in wild grapevines (approx. $0.037 \mathrm{mg} / \mathrm{g}$ ) than in domesticated cultivars $(0.015 \mathrm{mg} / \mathrm{g})$. 
The total content of pentacyclic triterpenoids ranged from $0.36 \mathrm{mg} / \mathrm{g}$ of dry leaf weight in Merlot cultivar to $1.5 \mathrm{mg} / \mathrm{g}$ in wild $V$. labrusca $\mathrm{L}$., and it was generally much lower in the domesticated grapevines (approx. $0.7 \mathrm{mg} / \mathrm{g}$ ) than in the wild species (approx. $0.9 \mathrm{mg} / \mathrm{g}$ ). In the majority of the wild grapevines analyzed in this study, lupeol was the predominant pentacyclic compound, constituting (as a mixture with $\alpha$-amyrin) from $45 \%$ of total pentacyclic triterpenoids in V. vinifera subsp. sylvestris (Gmelin) Hegi to $75 \%$ in $V$. labrusca L. The only exception among wild grapevines was V. riparia Michx., with only $13 \%$ of lupeol, and $\beta$-amyrin as the prevailing pentacyclic compound (82\% of total pentacyclic triterpenoids).

Among the domesticated grapevines, lupeol is prevailing only in one cultivar, Gamay (the mixture of lupeol and $\alpha$-amyrin constituting $67 \%$ of total pentacyclic triterpenoids). In Cabernet Sauvignon, Marselan and Merlot, taraxerol was predominating (46, 58 and $62 \%$ of the sum of pentacyclic triterpenoids, respectively). The content of $\beta$-amyrin ranged from approx. $0.11 \mathrm{mg} / \mathrm{g}$ in Merlot to $0.19 \mathrm{mg} / \mathrm{g}$ in Cabernet Sauvignon, and it was not the dominant compound in any of domesticated cultivars. Interestingly, a similar level of taraxerol was found in domesticated Vitis vinifera cultivars and in their oldest wild ancestor V. vinifera subsp. sylvestris (Gmelin) Hegi.

\subsection{Conclusions}

The dendrogram of hierarchical clustering on principal components (HCPC) of the quantified steroids and triterpenoids in all samples (Fig. 4) suggests that the analyzed group of molecules may be an important phenotypic trait of Vitis plants. Indeed, two main types of clusters can be observed: the first one grouped the domesticated grapevines together, and the other showed strong similarities of steroid and triterpenoid profiles among the wild ones. Furthermore, the results seem to predict phylogenetic relationships of domesticated $V$. vinifera 
cultivars. As instance, Cabernet Sauvignon and Merlot were clustered together which may be due to their common parent Cabernet Franc (Boursiquot et al., 2009). Unexpectedly, $V$. vinifera cv. Marselan was grouped apart from Merlot and Cabernet Sauvignon, although the latter is involved in its parentage. Perhaps, the genetic background of Grenache, which is another parent of Marselan, prevails in terms of steroids and triterpenoids against the remaining cultivars of its origin (http://www.vivc.de). In turn, Gamay (Pinot Noir x Heunisch Weiss (also named Gouais Blanc)) was grouped along with Cabernet Sauvignon and Merlot, even if a close kinship of these cultivars was undetected (Terral et al., 2010). An advanced study of hybrid domesticated grapevines varieties and their respective parents is needed in order to verify an importance of steroid and triterpenoid profile in the determination of grapevines origins.

Moreover, the results obtained in the current study confirm that the leaves of numerous domesticated grapevines showed the profile of pentacyclic triterpenoids, which are generally considered as secondary metabolites, with predominating lupeol or taraxerol. For example, the division of eight cultivars from the Upper Rhine Valley into lupeol- or taraxerolrich groups was reported previously (Pensec et al., 2016). These differential triterpene contents could not be directly correlated to differential susceptibility to some pathogens, since the two groups show similar levels of susceptibility to $P$. viticola and E. necator, however, some observations could indicate that the cultivars with high lupeol contents were more resistant to Esca, a grapevine trunk disease, than those with a high taraxerol content (Pensec et al., 2016). Concerning sterols, in some species the profile of these compounds were demonstrated to be an important feature in the context of tolerance to abiotic stress as they are substantial constituents of cells membranes playing function in their structure and dynamics (Wang et al., 2017; Posé et al., 2009). A relatively higher amount of sterols in the wild 
grapevines comparing with the domesticated ones reported herein, may partially explain their general insusceptibility to drought, high/low temperature, UV radiation, or salinity.

The content of steroids and triterpenoids in the grapevines leaves is comparable with those from other plant species. However, the amount of these molecules can be significantly higher, e.g., in leaves of evergreen plants like lingonberry (Vaccinium vitis-idaea, Ericaceae), or much lower, e.g., in leaves of herbal plants like marigold (Calendula officinalis, Asteraceae) (Szakiel et al., 2012a; Niżyński et al., 2015). Thus, the biosynthetic ability in the production of triterpenoids varies in plants which can reflect the participation of these compounds in defenses. Nevertheless, a possible direct correlation between steroid and triterpenoid profile of Vitis plants and their resistance to common pathogens and extreme environmental conditions is worth further investigations.

\section{Experimental}

\subsection{Plant material}

The four wild Vitis spp. cultivars of interest (V. aestivalis Michx., V. labrusca L., V. riparia Michx. and V. vinifera subsp. sylvestris (Gmelin) Hegi were introduced from North America and France between 1963 and 2000 at St Louis experimental field in Villenave d'Ornon, France. The vineyard belongs to INRA-Bordeaux germplasm collection and is managed by the UMR EGFV (Villenave d'Ornon, France). Descriptive sheets (e.g. voucher specimens) of wild Vitis plants can be found at https://www.bordeaux.inra.fr/ampelobase. The four $V$. vinifera varieties (Cabernet Sauvignon, Gamay, Marselan and Merlot) were planted in 2009 in the "Vitadapt" experimental field and cultivated by the INRA and the ISVV, Villenave d'Ornon, France. All plants were similarly grafted and are managed by conventional methods. For each cultivar, ten mature fully expanded leaves (approximately leaves at the sixth position from the apex, and located always in the same orientation in the vines) were collected in 
October 2016 from plants with no evidence of disease or stress symptoms. The samples were freezed at $-80^{\circ} \mathrm{C}$ for at least $72 \mathrm{~h}$, and then lyophilized before extraction.

\subsection{Extraction and fractionation}

The preparation of samples was performed according to the method used by Szakiel et al. (2012a,b). The freeze-dried plant material (1 g) was grounded to a fine powder in a grinding mortar, and extracted with $100 \mathrm{ml}$ of diethyl ether (99.5\%, POCH S.A., Gliwice, Poland) in Soxhlet apparathus for $8 \mathrm{~h}$. The obtained extracts were evaporated to dryness at $40^{\circ} \mathrm{C}$ under reduced pressure, then fractionated by prep. TLC on $20 \mathrm{~cm}$ x $20 \mathrm{~cm}$ glass plates coated with a $0.25 \mathrm{~mm}$ layer of silica gel 60G (Merck, Darmstadt, Germany) in a solvent system $\mathrm{CHCl}_{3} / \mathrm{MeOH}(97: 3, \mathrm{v} / \mathrm{v})$. The fractions containing free (non-esterified) neutral steroids and triterpenoids (alcohols, aldehydes and ketones) were localized on plates by comparison with standard of sitosterol and $\alpha$-amyrin. The standards were visualized by spraying the relevant part of the plate with $50 \% \mathrm{H}_{2} \mathrm{SO}_{4}$, followed by heating with a hot-air stream. Subsequently, the fraction was eluted from the gel with diethyl ether and directly analyzed by GC-MS/FID.

\subsection{Identification and quantification of steroids and triterpenoids by GC-MS/FID}

The analyses were performed using an Agilent Technologies 7890A gas chromatograph (Perlan Technologies, Warsaw, Poland) coupled to 5975C mass spectrometric detector and equipped with a flame ionization detector, FID. All the samples were dissolved in diethyl ether/methanol (5:1, v/v) and a volume of 1-4 $\mu$ l was applied by split injection 1:10. The GC separation was made on a HP-5MS UI column of $30 \mathrm{~m}$ x $0.25 \mathrm{~mm}$ i.d., film thickness $0.25 \mu \mathrm{m}$ (Agilent Technologies) in the temperature programme: initial temperature of $160^{\circ} \mathrm{C}$ held for 2 min, then increased to $280^{\circ} \mathrm{C}$ at $5^{\circ} \mathrm{C} / \mathrm{min}$ and the final temperature of $280^{\circ} \mathrm{C}$ held for further $44 \mathrm{~min}$ with constant helium flow rate of $1 \mathrm{ml} / \mathrm{min}$. For GC-MS/FID detection the following parameters were employed: inlet and a flame ionization detector (FID) temp. $290{ }^{\circ} \mathrm{C}$, MS 
transfer line temp. $275^{\circ} \mathrm{C}$, quadrupole temp. $150{ }^{\circ} \mathrm{C}$, ion source temp. $230{ }^{\circ} \mathrm{C}, \mathrm{EI} 70 \mathrm{eV}, \mathrm{m} / \mathrm{z}$ range 33-500; FID-H $\mathrm{H}_{2}$ flow $30 \mathrm{ml} / \mathrm{min}$ (hydrogen generator), air flow $400 \mathrm{ml} / \mathrm{min}$. The individual compounds were identified by comparing their mass spectra with library data from Wiley 9th ED. \& NIST 2008 Lib. SW (Version 2010) or data from the literature, and by comparison of their retention times and corresponding mass spectra with those of authentic standards: $\alpha$-amyrin (Roth, Karlsruhe, Germany); $\beta$-amyrin, campesterol, sitosterol, and stigmasterol (Sigma-Aldrich Steinheim, Germany). The identified compounds were quantified with the use of a flame ionization detector (FID). In case of coelution, the manual peak integration was applied for precise measurement of peak areas. Quantitation was made using the external standard method based on calibration curves determined for typical representatives of each triterpenoid group: $\alpha$-amyrin for monohydroxyalcohols, and stigmasterol for steroids. Calibration curves were drawn between the peaks areas versus the concentration of $\alpha$-amyrin (linear regression equation $\mathrm{y}=45800 \mathrm{x}-300$ ) and stigmasterol $(y=35900 x-550)$ in the range of $0.002-2.0 \mathrm{mg} / \mathrm{ml}$. The correlation coefficient $\left(\mathrm{r}^{2}\right)$ values of $\alpha-$ amyrin was 0.999 and for stigmasterol 0.998 . RSD values of peak areas were less than $4 \%$. The LOD (Limit of Detection) was determined by analysis of samples with decreasing level of concentration of analyte, value for $\alpha$-amyrin was $0.8 \mu \mathrm{g} / \mathrm{ml}$, for stigmasterol $1.0 \mu \mathrm{g} / \mathrm{ml}$. A $2.5 \mu \mathrm{g} / \mathrm{ml}$ and $3.2 \mu \mathrm{g} / \mathrm{ml}$ limit of quantification (LOQ) was attained for $\alpha$-amyrin and stigmasterol, respectively.

\subsection{Statistical analysis of data}

The results presented consist of the mean values \pm standard deviation (s.d.) obtained from samples analyzed in triplicates. Hierarchical clustering on principal components (HCPC) with Manhattan distance measure was performed in $\mathrm{R}$ software version 3.4 .3 using the FactoMineR plugin. 


\section{Conflict of interest}

All authors declare that they have no conflict of interest.

\section{Acknowledgements}

We thank the Institut National de la Recherche Agronomique (INRA) Bordeaux-Aquitaine for their kind permission for collecting wild grapevine leaves in their vineyards.

The study was performed owing to the financial support of the French Government and the French Embassy in Poland.

Analyses were carried out with the use of CePT infrastructure financed by the European Union—the European Regional Development Fund (Agreement POIG.02.02.00-14-024/08$00)$.

\section{References}

Batovska, D.I., Todorova, I.T., Bankova, V.S., Parushev, S.P., Atanassov, A.I., Hvarleva, T.D., Djakova, G.J., Popov, S.S., 2008. Seasonal variations in the chemical composition of vinegrape leaf surface. Nat. Prod. Res. 14, 1231-1236. https://doi.org/10.1080/14786410701725865

Batovska, D.I., Todorova, I.T., Parushev, S.P., Nedelcheva, D.V., Bankova, V.S., Popov, S.S., Ivanova, I.I., Batovski, S.A., 2009. Biomarkers for the prediction of the resistance and susceptibility of grapevine leaves to downy mildew. J. Plant. Physiol. 166, 781-785. https://doi:10.1016/j.jplph.2008.08.008

Batovska, D.I., Todorova, I.T., Djakova, G.J., Ivanova, I.I., Popov, S.S., 2010. GC-MS analysis of the leaf surface components of four Bulgarian grapevines grown under different conditions. Nat. Prod. Res. 24, 1027-1032. https://doi.org/10.1080/14786410902904376

Berli, F.J., Moreno, D., Piccoli, P., Hespanhol-Viana, L., Silva, M.F., Bressan-Smith, R., Cavagnaro, J.B, Bottini, R., 2010. Abscisic acid is involved in the response of grape (Vitis 
vinifera L.) cv. Malbec leaf tissues to ultraviolet-B radiation by enhancing ultravioletabsorbing compounds, antioxidant enzymes and membrane sterols. Plant, Cell and Environ. 33, 1-10. https://doi:10.1111/j.1365-3040.2009.02044.x

Boursiquot, J.M., Lacombe, T., Laucou, V., Julliard, S., Perrin, F.X., Lanier, N., Legrand, D., Meredith, S., This, P., 2009. Parentage of Merlot and related winegrape cultivars of southwestern France: discovery of the missing link. Aust. J. Grape Wine R. 15, 144-155. https://doi:10.1111/j.1755-0238.2008.00041.x

De Cortázar-Atauri, I.G., Duchêne, E., Destrac-Irvine, A., Barbeau, G., Rességuier, L., Lacombe, T., Parker, A.K., Saurin, N., Leeuwen, C., 2017. Grapevine phenology in France: from past-observations to future evolutions in the context of climate change. OENO One 51, 115-126. https://doi:10.20870/oeno-one.2016.0.0.1622

Gil, M., Pontin, M., Berli, F., Bottini, R., Piccoli, P., 2012. Metabolism of terpenes in the response of grape (Vitis vinifera L.) leaf tissues to UV-B radiation. Phytochemistry 77, 89-98. https://doi:10.1016/j.phytochem.2011.12.011

Niżyński, B., Alsoufi, A.S.M., Pączkowski, C., Długosz, M., Szakiel, A., 2015. The content of free and esterified triterpenoids of the native marigold (Calendula officinalis) plant and its modifications in in vitro cultures. Phytochem. Lett. 11, 410-417. https://doi.org/10.1016/j.phytol.2014.12.017

Orhan, D.D., Orhan, N., Özçelik, B., Ergun, F., 2009. Biological activities of Vitis vinifera L. leaves. Turk. J. Biol. 33, 341-348. https://doi:10.3906/biy-0806-17

Özer, N., Şabudak, T., Özer, C., Gindro, K., Schnee, S., Solak, E., 2017. Investigations on the role of cuticular wax in resistance to powdery mildew in grapevine. J. Gen. Plant Pathol. 83, 316-328. https://doi:10.1007/s10327-017-0728-5

Pacifico, S., D’Abrosca, B., Scognamiglio, M., Gallicchio, M., Galasso, S., Monaco, P., Fiorentino, A., 2013. Antioxidant polyphenolic constituents of Vitis x Labruscana cv. 
'Isabella' leaves. The Open Natural Products Journal 6, 5-11. https://doi:10.2174/1874848101306010005

Pensec, F., Szakiel, A., Pączkowski, C., Woźniak, A., Grabarczyk, M., Bertsch, C., Fischer, M.J.C., Chong, J., 2016. Characterization of triterpenoid profiles and triterpene synthase expression in the leaves of eight Vitis vinifera cultivars grown in the Upper Rhine Valley. J. Plant Res. 129, 499-512. https://doi:10.1007/s10265-016-0797-0

Posé, D., Castanedo, I., Borsani, O., Nieto, B., Rosado, A., Taconnat, L., Ferrer, A., Dolan, L., Valpuesta, V., Botella, M.A., 2009. Identification of the Arabidopsis dry2/sqe1-5 mutant revealsa central role for sterols in drought tolerance and regulation of reactive oxygen species. The Plant Journal 59, 63-76. https://doi:10.1111/j.1365-313X.2009.03849.x

Rodríguez, S., Garda, H.A., Heinzen, H., Moyna, P., 1997. Effect of plant monofunctional pentacyclic triterpenes on the dynamic and structural properties of dipalmitoylphosphatidylcholine bilayers. Chem. Phys. Lipids 89, 119-130. https://doi.org/10.1016/S0009-3084(97)00068-6

Shai, L.J., McGaw, L.J., Aderogba, M.A., Mdee, L.K., Eloff, J.N., 2008. Four pentacyclic triterpenoids with antifungal and antibacterial activity from Curtisia dentata (Burm.f) C.A. Sm. Leaves. J. Ethnopharmacol. 119, 238-244. https://doi:10.1016/j.jep.2008.06.036

Szakiel, A., Pączkowski, C., Koivuniemi, H., Huttunen, S., 2012a. Comparison of the triterpenoid content of berries and leaves of lingonberry Vaccinium vitis-idaea from Finland and Poland. J. Agric. Food Chem. 60, 4994-5002. https://doi:10.1021/jf300375b

Szakiel, A., Pączkowski, C., Huttunen, S., 2012b. Triterpenoid content of berries and leaves of bilberry Vaccinium myrtillus from Finland and Poland. J. Agric. Food Chem. 60, 1183911849. https://doi:10.1021/jf3046895

Terral, J.F., Tabard, E., Bouby, L., Ivorra, S., Pastor, T., Figueiral, I., Picq, S., Chevance, J.B., Jung, C., Fabre, L., Tardy, C., Compan, M., Bacilieri, R., Lacombe, T., This, P., 2010. 
Evolution and history of grapevine (Vitis vinifera) under domestication: new morphometric perspectives to understand seed domestication syndrome and reveal origins of ancient European cultivars. Ann. Bot. 105, 443-455. https://doi.org/10.1093/aob/mcp298

Van Leeuwen, C. and Destrac-Irvine, A., 2017. Modified grape composition under climate change conditions requires adaptations in the vineyard. OENO One 51, 147-154. https://doi.org/10.20870/oeno-one.2016.0.0.1647

Wang, J., Juliani, H.R., Jespersen, D., Huang, B., 2017. Differential profiles of membrane proteins, fatty acids, and sterols associated with genetic variations in heat tolerance for a perennial grass species, hard fescue (Festuca Trachyphylla). Environ. Exp. Bot. 140, 65-75. https://doi.org/10.1016/j.envexpbot.2017.05.014 http://www.vivc.de/index.php?r=passport\%2Fview\&id=16383 Last modified: June 2018. 


\section{Figure captions:}

Fig. 1. Representative GC-FID chromatograms of the fraction containing steroids and neutral triterpenoids from diethyl ether leaf extracts of grapevines. Cholesterol (1); campesterol (2); stigmasterol (3); clionasterol (4); sitosterol (5); sitostanol (6); taraxerol (7); $\beta$-amyrin (8); sitosterol acetate (9); lupeol/ $\alpha$-amyrin (10+11); 24-methylenecycloartanol (12); lupeol acetate (13).

Fig. 2. Chemical structures of steroids and triterpenoids identified in Vitis spp. leaf diethyl ether extracts: cholesterol (1), campesterol (2), stigmasterol (3), clionasterol (4), sitosterol (5), sitostanol (6), taraxerol (7), $\beta$-amyrin (8), sitosterol acetate (9), lupeol (10), $\alpha$-amyrin (11), 24 methylenecycloartanol (12), lupeol acetate (13).

Fig. 3. Quantification of pentacyclic triterpenoids in grapevine leaf diethyl ether extracts based on GC-MS/FID analysis.

Fig. 4. Cluster dendrogram performed by hierarchical clustering on principal components (HCPC) showing the discrimination of wild and domesticated grapevines Vitis spp. based on the composition of triterpenoids in leaves diethyl ether extracts. 


\section{Table 1.}

Triterpenoid content in the leaves of Vitis aestivalis Michx., Vitis labrusca L., Vitis riparia Michx. and Vitis vinifera subsp. sylvestris (Gmelin) Hegi

\begin{tabular}{|c|c|c|c|c|}
\hline Compound & $\begin{array}{c}V . \\
\text { aestivalis } \\
\text { Michx. }\end{array}$ & $\begin{array}{c}V . \\
\text { labrusca } \\
\text { L. }\end{array}$ & $\begin{array}{l}\text { V. riparia } \\
\text { Michx. }\end{array}$ & $\begin{array}{c}V . \\
\text { vinifera } \\
\text { subsp. } \\
\text { sylvestris } \\
\text { (Gmelin) } \\
\text { Hegi }\end{array}$ \\
\hline & \multicolumn{4}{|c|}{$\left(\mu \mathrm{g} \mathrm{g}{ }^{-1}\right.$ d.w. \pm S.D. $)$} \\
\hline Steroids: & & & & \\
\hline Cholesterol (1) & $\begin{array}{l}37.51 \pm \\
5.63\end{array}$ & $\begin{array}{l}44.41 \pm \\
6.66\end{array}$ & $\begin{array}{c}29.31 \pm \\
4.40\end{array}$ & $\begin{array}{c}49.12 \pm \\
7.37\end{array}$ \\
\hline Campesterol (2) & $\begin{array}{c}45.14 \pm \\
4.51\end{array}$ & $\begin{array}{c}42.90 \pm \\
4.29\end{array}$ & $\begin{array}{c}24.62 \pm \\
2.46\end{array}$ & $\begin{array}{l}38.25 \pm \\
3.82\end{array}$ \\
\hline Stigmasterol (3) & $\begin{array}{c}134.58 \pm \\
12.11\end{array}$ & $\begin{array}{l}85.74 \pm \\
7.72\end{array}$ & $\begin{array}{l}90.70 \pm \\
8.16\end{array}$ & $\begin{array}{c}106.93 \pm \\
9.62\end{array}$ \\
\hline Clionasterol (4) & & & & $\begin{array}{c}310.14 \pm \\
46.52\end{array}$ \\
\hline Sitosterol (5) & $\begin{array}{l}735.69 \pm \\
73.57\end{array}$ & $\begin{array}{l}714.83 \pm \\
71.48\end{array}$ & $\begin{array}{c}822.07 \pm \\
82.21\end{array}$ & $\begin{array}{c}419.73 \pm \\
41.97\end{array}$ \\
\hline Sitostanol (6) & & $\begin{array}{l}55.02 \pm \\
8.25\end{array}$ & $\begin{array}{c}32.77 \pm \\
4.92\end{array}$ & \\
\hline Sitosterol acetate $(\mathbf{9})$ & $\begin{array}{c}10.30 \pm \\
0.67\end{array}$ & & $\begin{array}{l}21.01 \pm \\
3.15\end{array}$ & $\begin{array}{c}70.66 \pm \\
10.60\end{array}$ \\
\hline $\begin{array}{l}\text { 24-Methylenecycloartanol } \\
\text { (12) }\end{array}$ & $\begin{array}{l}49.57 \pm \\
5.95\end{array}$ & $\begin{array}{c}179.46 \pm \\
21.53\end{array}$ & $\begin{array}{l}52.00 \pm \\
6.24\end{array}$ & $\begin{array}{c}20.94 \pm \\
2.51\end{array}$ \\
\hline Sum & 1012.79 & 1122.35 & 1072.48 & 1015.77 \\
\hline \multicolumn{5}{|l|}{ Pentacyclic triterpenoids: } \\
\hline Taraxerol (7) & $\begin{array}{l}49.70 \pm \\
7.45\end{array}$ & $\begin{array}{c}14.23 \pm \\
2.13\end{array}$ & $\begin{array}{l}26.33 \pm \\
3.95\end{array}$ & $\begin{array}{c}269.35 \pm \\
40.40\end{array}$ \\
\hline$\beta$-Amyrin (8) & $\begin{array}{c}143.23 \pm \\
12.89\end{array}$ & $\begin{array}{c}363.23 \pm \\
32.69\end{array}$ & $\begin{array}{c}546.48 \pm \\
49.18\end{array}$ & $\begin{array}{c}218.82 \pm \\
19.69\end{array}$ \\
\hline Lupeol/a-Amyrin (10+11) & $\begin{array}{c}369.16 \pm \\
40.61\end{array}$ & $\begin{array}{l}1172.94 \\
\pm 129.02\end{array}$ & $\begin{array}{c}88.37 \pm \\
9.72\end{array}$ & $\begin{array}{c}397.19 \pm \\
43.69\end{array}$ \\
\hline Lupeol acetate (13) & $\begin{array}{c}3.04 \pm \\
0.24\end{array}$ & $\begin{array}{r}8.00 \pm \\
0.64\end{array}$ & $\begin{array}{c}3.75 \pm \\
0.30\end{array}$ & $\begin{array}{c}6.95 \pm \\
0.56\end{array}$ \\
\hline Sum & 565.13 & 1558.39 & 664.93 & 892.31 \\
\hline Total & 1577.92 & 2680.75 & 1737.41 & 1908.08 \\
\hline
\end{tabular}

Results are referenced to leaf dry weight and expressed in $\mu \mathrm{g} \mathrm{g}^{-1}$ as the means \pm S.D. of three independent samples analysed in triplicate. 


\section{Table 2.}

Triterpenoid content in the leaves of Vitis vinifera cv. Cabernet Sauvignon, Gamay, Marselan, and Merlot

\begin{tabular}{|c|c|c|c|c|}
\hline Compound & $\begin{array}{c}\text { V. vinifera } \\
\text { cv. } \\
\text { Cabernet } \\
\text { Sauvignon }\end{array}$ & $\begin{array}{c}\text { V. vinifera } \\
\text { cv. } \\
\text { Gamay }\end{array}$ & $\begin{array}{l}\text { V. vinifera } \\
\text { cv. } \\
\text { Marselan }\end{array}$ & $\begin{array}{l}\text { V. vinifera } \\
\text { cv. Merlot }\end{array}$ \\
\hline & \multicolumn{4}{|c|}{$\left(\mu \mathrm{g} \mathrm{g}^{-1}\right.$ d.w. \pm S.D. $)$} \\
\hline \multicolumn{5}{|l|}{ Steroids: } \\
\hline Cholesterol (1) & $\begin{array}{l}20.17 \pm \\
3.02\end{array}$ & $33.91 \pm$ & $\begin{array}{l}50.50 \pm \\
7.57\end{array}$ & $31.90 \pm$ \\
\hline Campesterol (2) & $\begin{array}{l}11.72 \pm \\
1.17\end{array}$ & $\begin{array}{l}13.60 \pm \\
1.22\end{array}$ & $\begin{array}{l}23.42 \pm \\
2.34\end{array}$ & $\begin{array}{l}12.47 \pm \\
1.25\end{array}$ \\
\hline Stigmasterol (3) & $\begin{array}{c}54.77 \pm \\
4.93\end{array}$ & $\begin{array}{l}50.74 \pm \\
4.57\end{array}$ & $\begin{array}{l}77.15 \pm \\
6.94\end{array}$ & $\begin{array}{c}45.66 \pm \\
4.11\end{array}$ \\
\hline Sitosterol (5) & $\begin{array}{l}537.24 \pm \\
53.72\end{array}$ & $\begin{array}{l}643.68 \pm \\
64.37\end{array}$ & $\begin{array}{l}1141.06 \pm \\
114.11\end{array}$ & $\begin{array}{l}486.77 \pm \\
48.68\end{array}$ \\
\hline Sitosterol acetate (9) & $\begin{array}{l}58.45 \pm \\
2.92\end{array}$ & $\begin{array}{c}11.43 \pm \\
0.86\end{array}$ & $\begin{array}{l}156.56 \pm \\
14.09\end{array}$ & $\begin{array}{l}16.41 \pm \\
1.64\end{array}$ \\
\hline $\begin{array}{l}\text { 24-Methylenecycloartanol } \\
\text { (12) }\end{array}$ & $\begin{array}{l}33.48 \pm \\
4.02\end{array}$ & $\begin{array}{l}52.45 \pm \\
4.72\end{array}$ & $\begin{array}{l}267.11 \pm \\
8.16\end{array}$ & $\begin{array}{l}49.03 \pm \\
5.88\end{array}$ \\
\hline Sum & 715.83 & 805.80 & 1715.80 & 642.24 \\
\hline \multicolumn{5}{|l|}{ Pentacyclic triterpenoids: } \\
\hline Taraxerol (7) & $\begin{array}{c}366.49 \pm \\
54.97\end{array}$ & $\begin{array}{c}145.77 \pm \\
14.58\end{array}$ & $\begin{array}{l}384.14 \pm \\
57.62\end{array}$ & $\begin{array}{l}226.66 \pm \\
34.00\end{array}$ \\
\hline$\beta$-Amyrin (8) & $\begin{array}{l}193.28 \pm \\
17.40\end{array}$ & $\begin{array}{c}168.84 \pm \\
16.88\end{array}$ & $\begin{array}{l}145.03 \pm \\
13.05\end{array}$ & $\begin{array}{l}105.15 \pm \\
9.46\end{array}$ \\
\hline Lupeol/a-Amyrin $(\mathbf{1 0 + 1 1 )}$ & $\begin{array}{l}220.14 \pm \\
24.22\end{array}$ & $\begin{array}{l}651.78 \pm \\
65.18\end{array}$ & $\begin{array}{l}91.65 \pm \\
10.08\end{array}$ & $\begin{array}{l}23.83 \pm \\
2.62\end{array}$ \\
\hline Lupeol acetate (13) & $\begin{array}{l}16.42 \pm \\
1.31\end{array}$ & & $\begin{array}{l}46.48 \pm \\
3.72\end{array}$ & $\begin{array}{c}10.18 \pm \\
0.81\end{array}$ \\
\hline Sum & 796.34 & 966.40 & 667.30 & 365.82 \\
\hline Total & 1512.17 & 1772.20 & 2383.09 & 1008.06 \\
\hline
\end{tabular}

Results are referenced to leaf dry weight and expressed $\mu \mathrm{g} \mathrm{g}^{-1}$ as the means \pm S.D. of three independent samples analysed in triplicate. 
Vitis vinifera subsp. sylvestris (Gmelin) Hegi

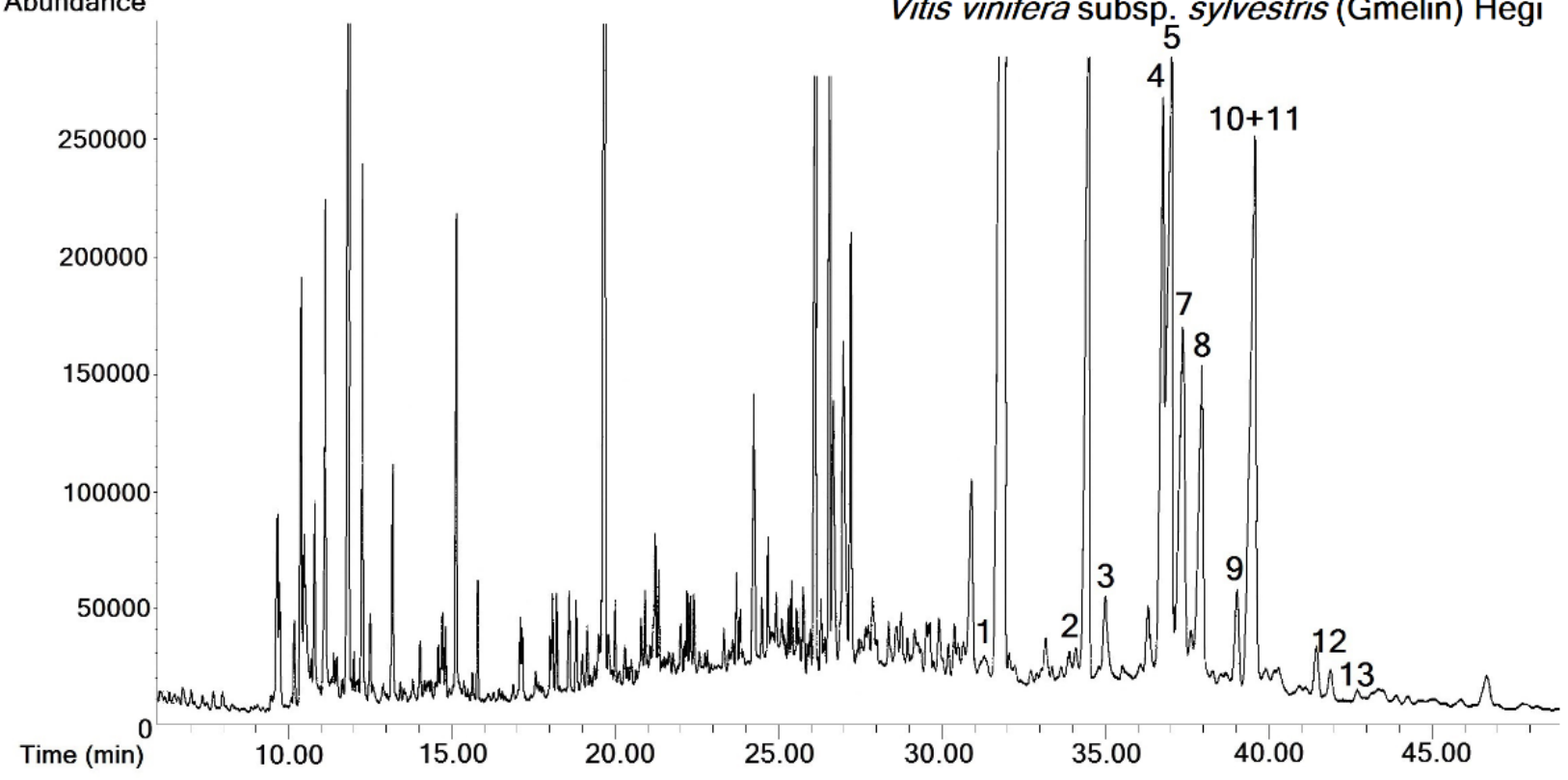

Abundance

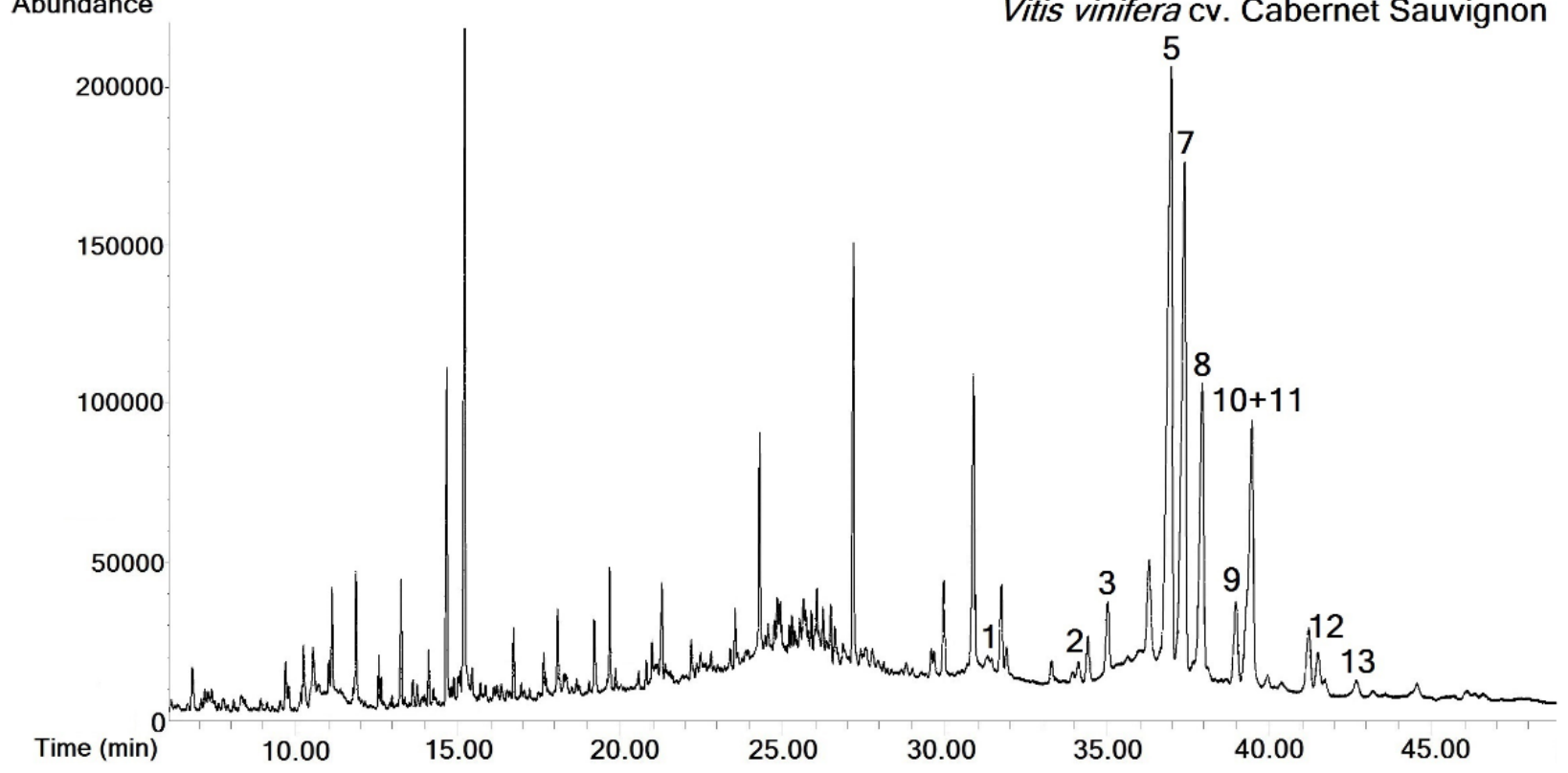

30.00

Vitis vinifera cv. Cabernet Sauvignon 


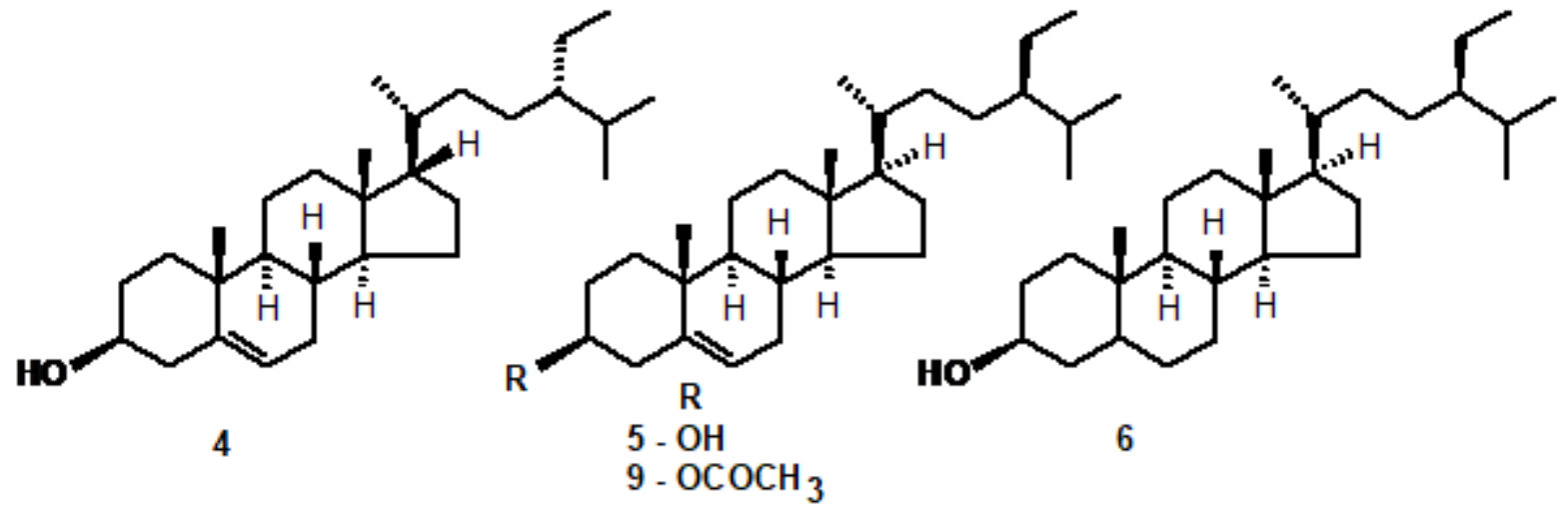

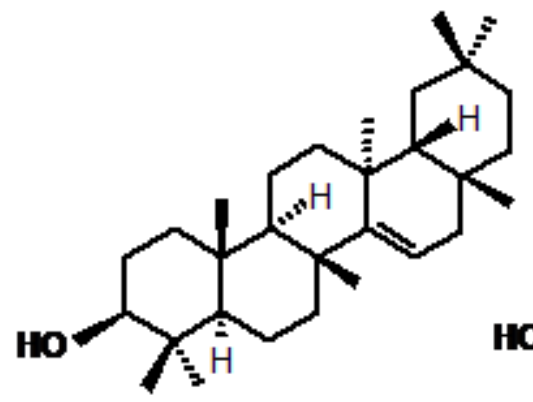

7

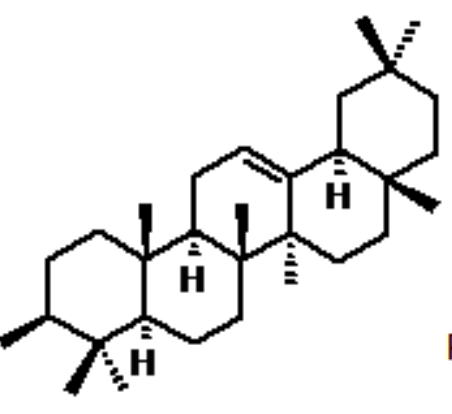

8

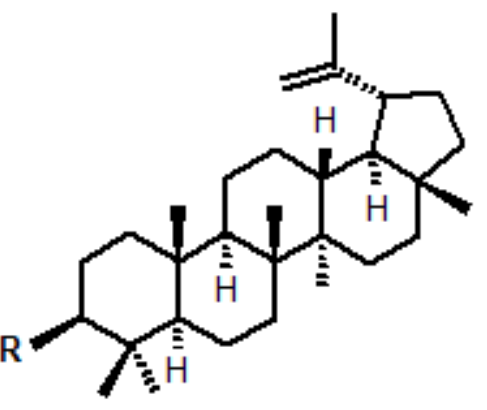

$R$

10 - $\mathrm{OH}$

$13-\mathrm{OCOCH}_{3}$

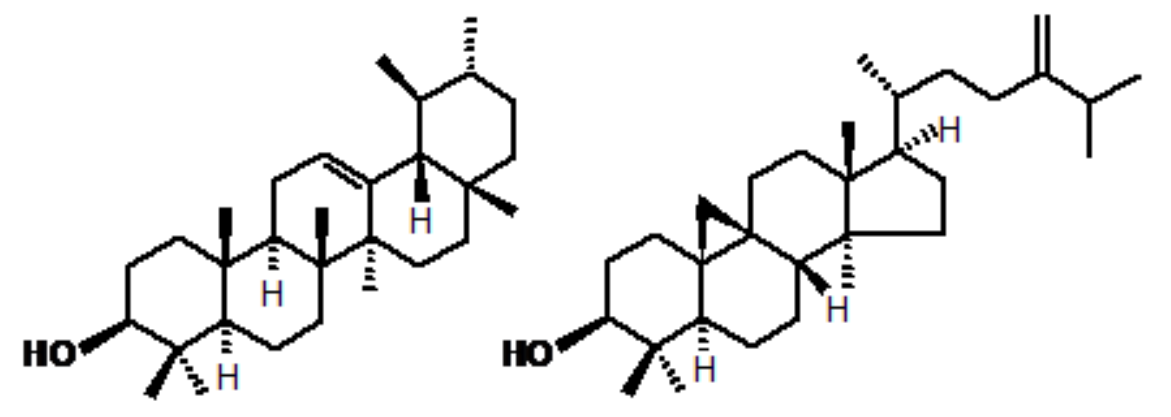




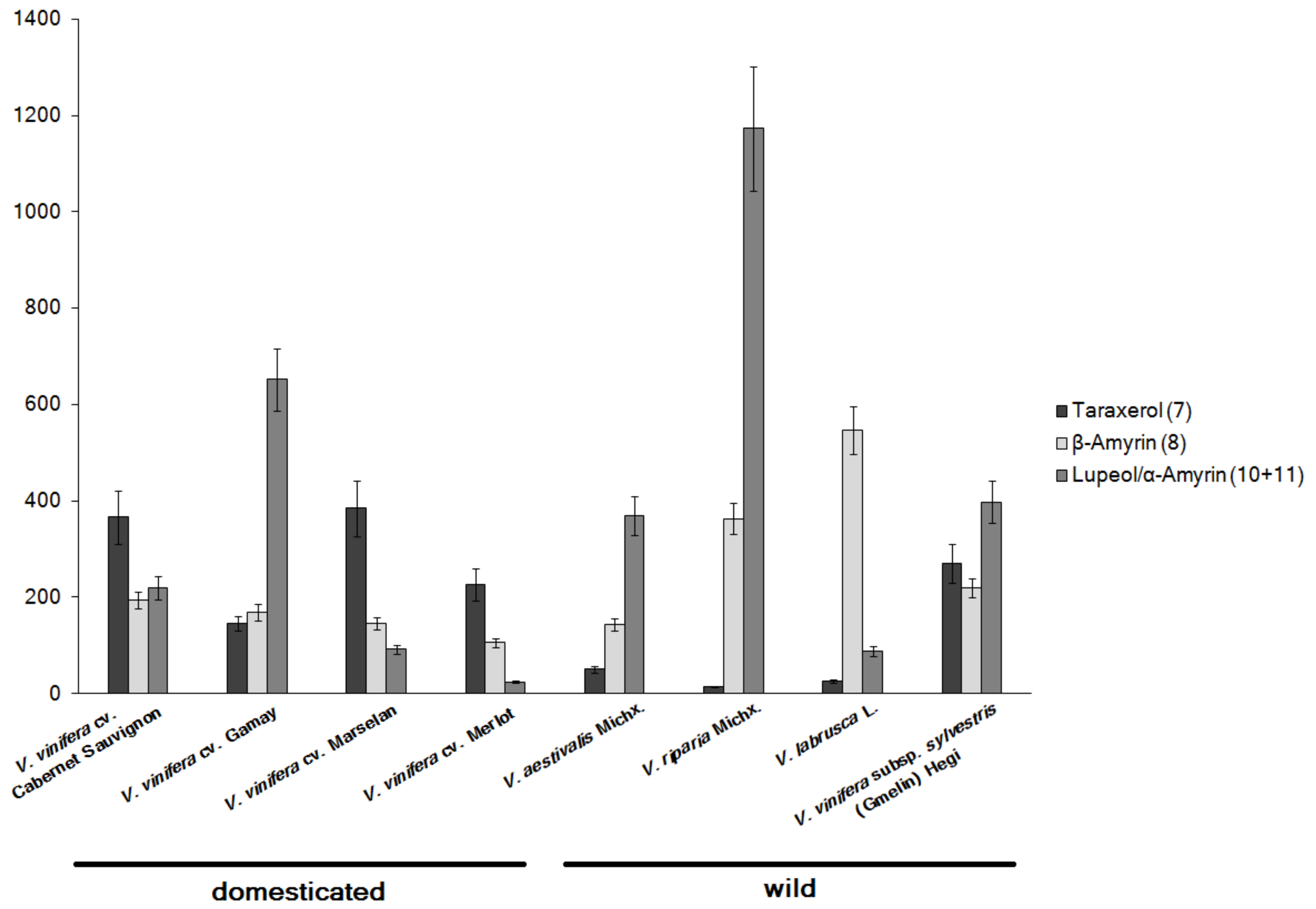




\section{Hierarchical tree}

Cluster dendrogram

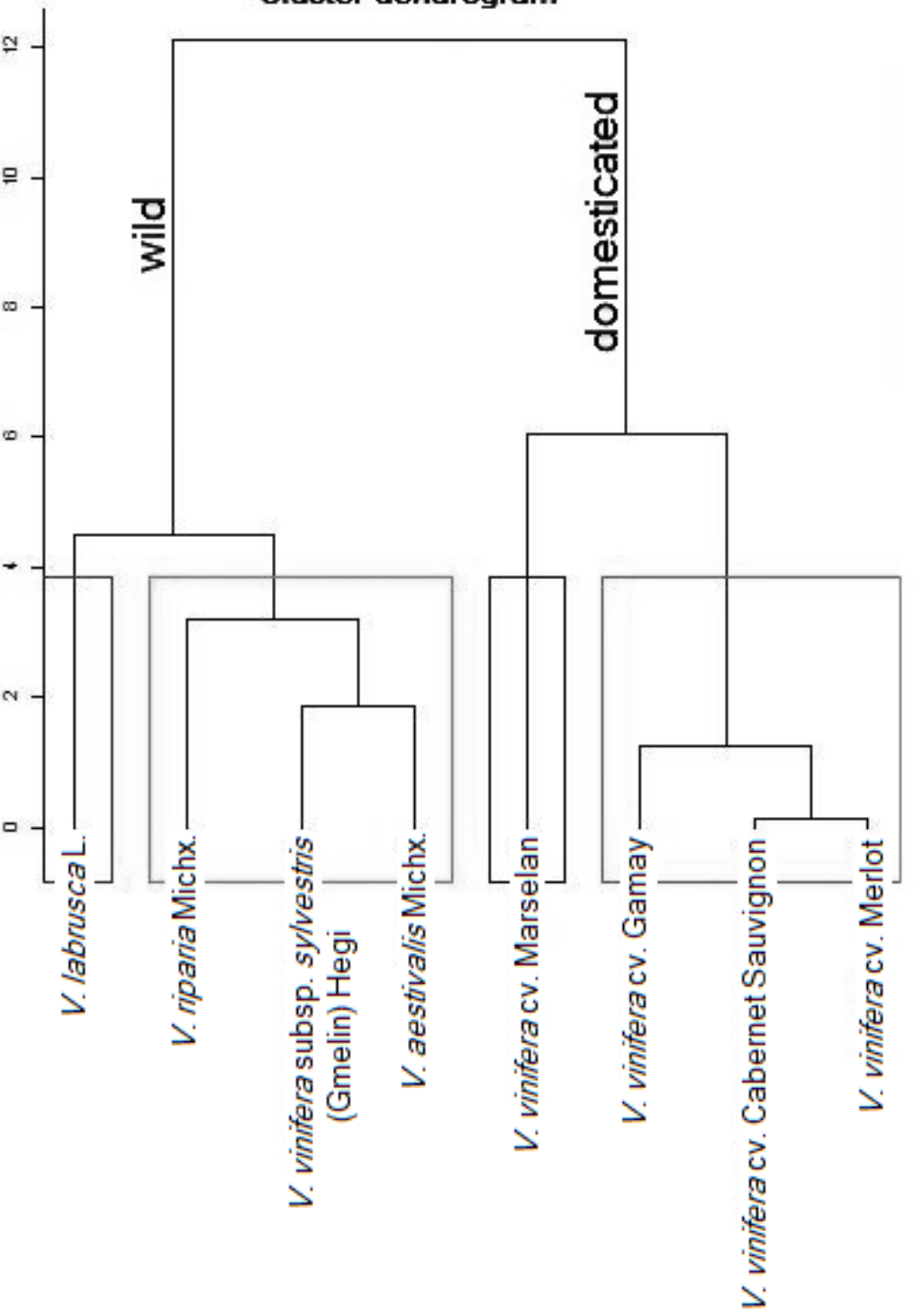




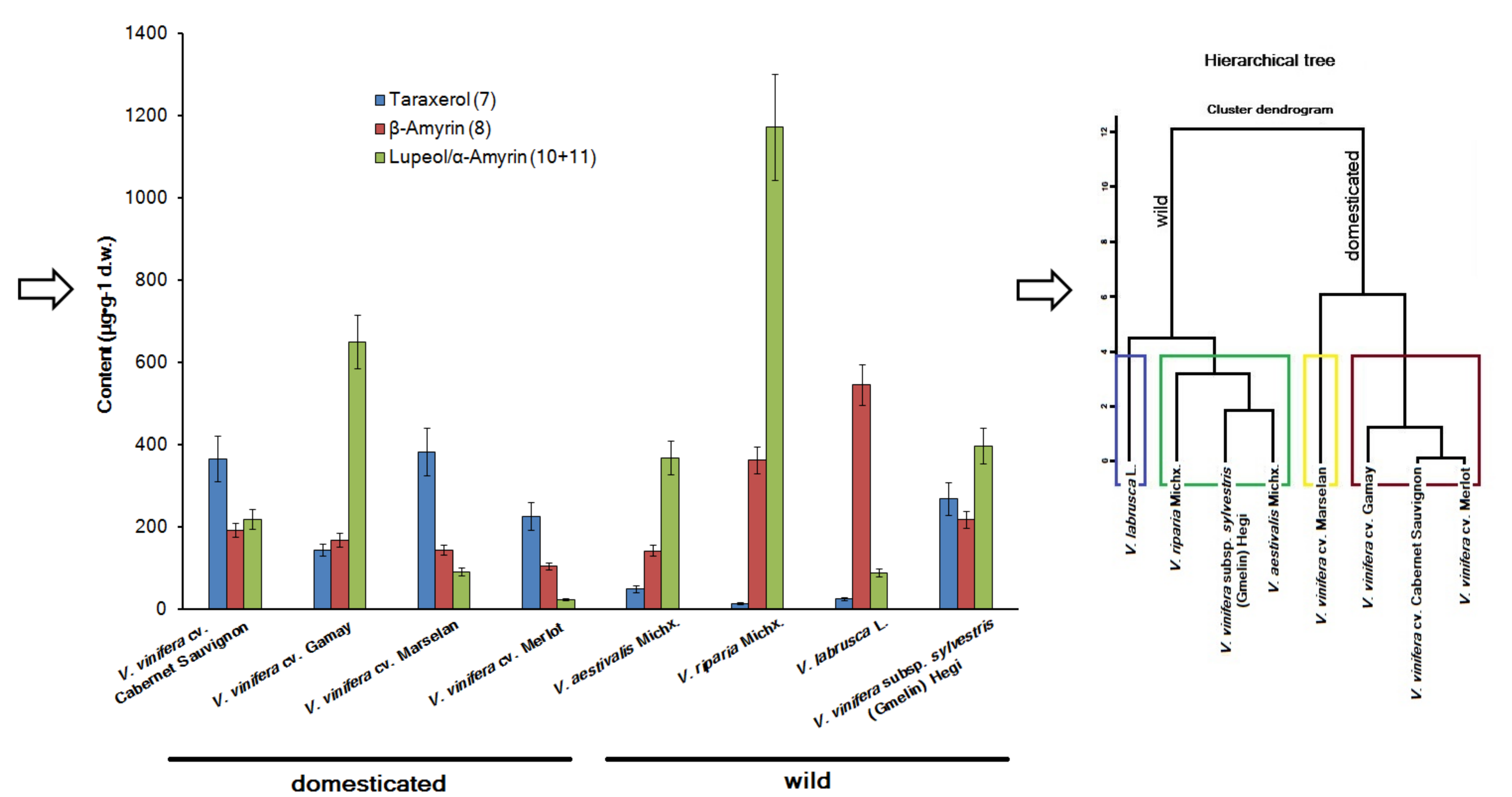

